\title{
Production Unit Model with The Approach to Knowledge based Industry in SMK Competence Expertise Clothing Design
}

\author{
M. Maeliah, Y. Jubaedah, N. Rohaeni \\ Department of Home Economic \\ Faculty of Technical and Vocational Education \\ Universitas Pendidikan Indonesia \\ Bandung, Indonesia \\ september_ghifar@yahoo.co.id
}

\begin{abstract}
This study was based on the fact that it is important to synchronize the competences of vocational school students or graduates and workplace requirements. The students should actually be equipped with abundant learning experiences tailored with the industrial requirements. The aim of this study was to produce a model production unit with the approach of Knowledge Based Industry Vocational Skills Competency in dressmaking. Specific targets to be achieved from this research is to produce: (1) The findings concerning the characteristics of the business management field of fashion in the opinion of the expert and practitioner, (2) Findings of the routine activities of the production units of clothing in Vocational Skills Competencing dressmaking, (3) Design models Unit Production Approach Knowledge with Based Industry Vocational Skills Competency in dressmaking, (4) Strengthening training programs in vocational competency fashion expertise. This research uses a descriptive method with the approach of Research and Development. This development studies are carried out in three stages, comprising: a preliminary study phase, the model development and validation of test models. The subjects consist of the students and master teachers on entrepreneurship subjects and productive skills in the vocational field of dressmaking. The data were collected through interviews, observation and documentation study. The results showed that, the design model of a production unit with the approach of Knowledge Based Industry in Vocational Skills Competency is designed to combine dressmaking boutiques and mass product system adapted to the adjustment in production processes adapted to the demands of working in the fashion industry and consumers needs. To implement the model developed should be supported by adequate competence, in order to obtain the findings and strengthen the need for training of fashion competency skills for learners in business practices at the production unit that pioneered SMK. The outcomes of this study are: (1) Design Approach models Production Unit with Knowledge Based Industry Vocational Skills Competency in dressmaking, (2) training program strengthening competence in vocational fashion expertise, $(3)$ the results of the research article is to be published in international journals.
\end{abstract}

Keywords-Model, Production Unit, Knowledge Based Industry, SMK Clothing Design

\section{INTRODUCTION}

Vocational High School (SMK), which has a role as a vocational educational institution, currently implemented in education has not been oriented toward production based training development but still limited to learning how to develop their knowledge and skills. SMK is not yet able to create the feel of the economy on business practices in the development of production units, because learning is more oriented to the delivery of content and practice of making the product which does not provide a learning experience and the formation of learners who are professionals in the areas of expertise such as dressmaking. Focusing on learning entrepreneurial and business management is still not optimized, so that a number of learners have dropped out of school and become unemployed, because they have no competence in accordance with the needs of the working world. The gap is in line with the opinions expressed by Suparno (2008: 1), saying "Competen job seekers have not Link and Match competence with industry". This phenomenon shows that vocational education has not been optimized as a unit to prepare students and graduates with the competence to suit the demands of the business and the industrial world. This assumption is in line with the study conducted by Samsudi (2005), who revealed that the "Implementation of learning in productive vocational program has not been effective, because the teacher is not optimalism in preparing the lesson plans and using learning approaches in teaching and learning process".

The era of globalization is loaded with information in the fields of economy, especially the development of the fashion industry in Indonesia. It requires people who are competent and professional to utilize the knowledge in product innovation that has spawned selling points both on a local, regional, national or international. This phenomenon is in line with that is extracted from Hadiwaratma (Ministry of Education, 2002: 574) concerning the nature of knowledge-based industries, that: The ability to generate and utilize knowledge to innovate is not only a determining factor of prosperity, but also a basis for creating a comparative advantage. How much more in the era of information and globalization, only skill based industry that 
will last, while only relying on cheap labor-based will stop and die.

Naylor (1989) in his research describes two models are considered the most successful programs in career and vocational education. Two models of programs that receive special attention are school program in a school and the learning environment combined. School within a school program works best when it includes no more than 25-100 learners are nurtured. This program shows the relationship face to face, either in the form of personal and individual teaching spacious. While the model of combined learning environment; vocational instruction provided in an environment where learners, teachers, employers, parents and the community is seen as a partner in a learning community that is open and interconnected. The relationship between students and teachers is emphasized on the formulation of common goals and decision-making, teamwork and group participation.

Learners with increased competence is developed through practice-oriented quality improvement and product development at school by involving the industry as a partner institution or institutions relevant partner. Kerka (1997) has conducted research related to learning in vocational education. The research result asserts that: "The focus of learning should be present in the formation of individual knowledge of active and major role of vocational education to facilitate the embodiment of knowledge through experience technique, and social context in a real world environment.

This effort is to meet the demands of the industrial world and the business world, so that there will be no gap between the competencies mastered by the vocational graduates and the competencies required in the workforce. hence, the need for a trigger to deliver innovation in the use of knowledge for economic and industrial growth is met. one model that can be developed in a productive learning in vocational skills is by applying the approach of knowledge based industry. this knowledge-based approach to the industry is an innovation in developing a production unit at smk, because is through the production unit learners will gain learning experience in managing a business in a professional manner.

\section{RESEARCH METHODS}

The research approach used to answer the research problems that have been formulated in this research is the Research and Development (R \& D). The step Research Research and Development in the first year a Preliminary Study. The location to conduct the research as a test development Vocational Skills Competency models is dressmaking centers in West Java, with the subject of the study consisting of students and senior teachers of the subjects being productive dressmaking skills. The data collection techniques used interview, observation and documentation study supported by the literature review. Findings of the model production unit with Knowledge Based Approach Industry Vocational Skills Competency in dressmaking is described in a narrative form of data presentation, and then analyzed qualitatively.

\section{THE RESULTS AND DISCUSSIONS}

\section{A. Description of Operation of Unit Production in dressmaking vocational Expertise}

The research results presented in this chapter is the answer to the research objectives that have been formulated before, especially with regard to: 1) The learning conditions and the implementation of production units obtained through the results of the initial survey, documentation study and interviews; 2) The design of the model production unit with Knowledge Based Approach Industry Vocational Skills Competency in dressmaking.

\section{1) The conditions in vocational learning}

The orientation of vocational education in improving the education and training of human resources by providing the knowledge and skills to learners in accordance SKKNI that can be applied to the world of work, so as to compete competitively in the world of work, HR including vocational learners, can increase competence through contextual experience particularly in the field of business which must comply with labor standards in the world of business and industry. Experience in the field of business, which can be pursued through the implementation of school Production Unit, as an integral part of the vocational education system in Indonesia plays an important role in improving the human resources (HR), especially graduates who are ready to work at the secondary level of appropriate expertise.

The implementation of learning in vocational school is generally carried out in theory and practice by applying the approach of Competency Based Training, Production Based Training and industry-based training. Learning is implemented in accordance with the Competency Standards and Basic Competency at the curriculum structure in accordance with the programmed time duration on the annual program and the semester system.

\section{a) Competency Based Training (Competency Based Training)}

Competency-based training is the process of teaching planning, implementation and assessment refering to the mastery of competencies of the learners. The aim of this approach is that the activities performed in the teaching process actually refer to and directed learners to achieving mastery of competencies that have been programmed jointly with business schools and industry.

\section{b) Based Training Production (Production Based Training)}

Production-based training is a learning process expertise or skills based procedures and standards designed to work real (real job) to produce goods or services in accordance with the demands of the market or the consumer.

\section{c) Industry-based training (learning at work)}

Learning in the workplace is a strategy in which each participant is undergoing a process of learning through direct work (learning by doing) on the real work. Its implementation is called Dual System Education (PSG) / Industrial Practice in accordance with the developed areas of expertise. PSG is a 
form of organization of education and vocational training that combines expertise in a systematic and synchronous education programs in schools and programs mastery gained through working directly in the world of work, targeted to reach a certain level of professional expertise.

Each learning activity needs to be followed up by conducting the assessment, which can be done on the process and outcomes of learning. The implementation progress and learning outcomes of the students are directed to measure and assess the performance of students with regard to aspects of knowledge, skills and attitudes; either directly when learners learning activities and indirectly, through evidence of learning outcomes in accordance with the performance criteria. The Assessment or National Competency Standards-based testing at SMK wich the regular assessments, include:

\section{a) Reguler Interval Of Competence}

The periodic assessments of competence performed to end the measure and assess each competency has been learned by the students as a whole. The results of these tests are recorded in the Card Study Results (KHS) and are reported in the book of education report (report card).

\section{b) Interval Level Of Qualification}

Regular assessment of the final qualification level is a comprehensive assessment, made to measure and assess the achievement of a unit type of competency / qualification level of learners who have studied at the end of the types of competency / qualification levels. The results of this assessment are recorded in the Card Study results, reported in the report card, and verified by internal and external parties for the issuance of a certificate of competence in accordance with the type and level.

\section{c) The Final Interval Of Education}

The mastery of some partial competence in a particular skill is not automatically a guarantee that the person concerned may be expressed professional / competent in these skills. This required that the assessment mechanism to measure in question is the ability to demonstrate its performance as a whole which reveal elements of the overall dimensions of competence in a job. Dimensional the elements of competency may include: task skills, task management skills, contingency management skiing, job / role environment skills and skills transfer.

\section{B. The Implementation Of Unit Production at SMK}

Learning approach applied to the productive programs in vocational implications for the development of business models that fit the demands of USANA world and the industrial world, where the ability to be shown by the students has been formulated in the National Competency Standards dressmaking expertise.

From interviews, observation and study of the documentation relating to production unit which is usually held at SMK, can be grouped into two, namely: Development of business oriented boutique business and enterprise development-oriented garment enterprises.
Documentation of the results of the study illustrate the learning fashion business that has been implemented as follows:

a. In general, SMK does not manage a production unit in a professional fashion, so that the students were given the task of making integrated experience on the subject in the production of clothing.

b. Only a small fraction, SMK is organized in a professional production unit, so that the students gain the real experience in accordance with the conditions in the business and industrial areas of the fashion world.

Other findings were obtained through observations and interviews described as follows.

\section{1) Business Management Clothing}

Fashion business management is developed in vocational comprising of boutique and business mass production. For a boutique business, learners make products according to that assigned by the master teacher at the subjects completed with the practical implementation in the laboratory.

SMK is organized in a professional production units, applying mass production system. Learners receive the learning experience and work (learning by doing), in accordance with the order of the consumer. Learners must produce appropriate fashion business targets planned by the production unit. Production units are managed by the school and Master teachers of the productive and entrepreneurial subjects.

\section{2) Business Training}

In the development of production units in vocational school, training is done in advance to equip the learners wich include:

\section{a. Knowledge of production equipment fashion \\ b. The operation of the technical skills of clothing production \\ c. Basic skills improvement tools fashion production}

\section{3) Quality of Products}

The quality of the products produced on one production unit managed in one vocational school in West Java, has demonstrated the appropriate quality standards mass production products. The products produced by the students in the production unit already has a sale value and worthy of business products that can be developed in a professional and marketing expansion in addition to improving product quality and quantity of production.

Efforts need to be made in maintaining and developing a robust industry in a compare is on, including the need to create innovative high a quality both in developing ideas, products and production processes. Reinforced by the opinions Hadiwaratma (Ministry of Education, 2002: 574), that: In a knowledge-based industry "rapid industry consuming industries slow". The definition of "fast" in question is serving tastes quickly in the market, quick in providing the options of new products and services to buyers who are increasingly oriented wich global products (E-commerce) as well as rapid as partners in the global or global manufacturing vendors. This 
opinion can be interpreted that, innovation is one key to the success of knowledge-based industries, because it depends on the ability to generate, collect and diffuse knowledge and apply it to produce new products and services. Innovation is not just limited to the use of "hard technologies" (hard technology), but also in the management system that is skilled and intelligent, flexible, adaptive, efficient, effective. In other words, it means the "totality of integrated intelligent management system".

Learning developed in CMS production unit must be oriented to the world of work containing the charge of education and training in entrepreneurship and business management, thus giving birth to graduates who have work competence relevant to the business and industrial world. The learning approach can integrate Competency Based Training and Production Based Training in providing a learning experience Knowledge Based Industry to the students in SMK.

Competency-based training is the process of teaching planning, implementation and assessment that refers to the mastery of competencies of the learners. The aim of this approach is that the activities performed in the teaching process actually refer and direct learners to achieve the mastery of competencies programmed together with business and industry. Production-based training is a learning process expertise or skill based on procedures and standards designed to work real (real job) to produce goods or services in accordance with the demands of the market or the consumer.

\section{C. $\quad$ The Draft Model Design Production Unit with Knowledge Based Approach Industry}

Model Production Unit with the approach of Knowledge Based Industry in vocational is developed to adapt the model production unit that has developed in the SMK, which combines the systems and mass production by boutique making some adjustments to the conditions that exist in the environment SMK West Java.

The Implementation of professionally managed production unit that is integrated with the productive and entrepreneurial learning. Initial design model of a production unit with the approach of Knowledge Based Industry in the study includeds several stages, namely: Business Planning, Business Training, Business Development, Evaluation and Follow Up.

\section{CONCLUSION}

From all the research activities it can be concluded as follows:

1. The implementation of learning in vocational school is implemented in theory and practice by applying the approach of Competency Based Training, Production Based Training and industry-based training.

2. The management of the fashion business developed in vocational school comprising of boutique and business mass production, with experiential learning through teacher-led training of mastery teachers of the subjects and is implemented in practical activities in the laboratory.

3. Model Production Unit with the approach of Knowledge Based Industry in vocational system combines the mass production and boutiques to make adjustments to the conditions that exist in the environment SMK West Java.

4. Model Production Unit with Knowledge Based Industry approach can be recommended as a viable model of production units implemented in Vocational Expertise dressmaking West Java.

\section{REFERENCES}

[1] Departemen Pendidikan Nasional, (2002). Sejarah Pendidikan Teknik dan Kejuruan di Indonesia: Membangun Manusia Produktif. Jakarta: Direktorat Jenderal Pendidikan Menengah Kejuruan.

[2] Kerka, S. (1997). Constructivism, Workplace Learning, and Vocational Education. Terdapat di [On line] http://www.ericdigests.org/19981/learning.htm (5 Oktober 2006).

[3] Naylor, M. (1989). Retaining At-Risk Students in Career and Vocational. Terdapat di [On line] http://www.ericdigests.org/pre9212/risk.htm (26 Oktober 2006).

[4] Samsudi. (2006). Pengembangan Model Pembelajaran Program Produktif Sekolah Menengah Kejuruan (Studi Model Preskriptif dengan Penerapan Learning Guide pada Program Keahlian Teknik Mekanik Otomotif). Bandung: Program Pascasarjana Universitas Pendidikan Indonesia.

[5] Suparno, Erman. (2008). Kompetensi, Jabatan Penghubung Dunia Pendidikan dan Industri. Terdapat di [On line] http://www.Edubenchmark.com/kompetensijembatanpenghubungduniap endidikanindustri.html (10 Februari 2008). 